\title{
Stage-level analysis: five years dedicated to the dental
}

\section{community}

Marian-Vladimir CONSTANTINESCU

DDS, PhD, Professor

Editor-in-Chief

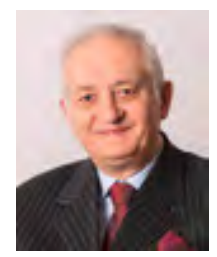

Dear readers,

Now, in the 5th year of the Stomatology Edu Journal's existence (Stoma Edu J), 1 have the pleasure and honor to carry out an analysis of the main events that have been going on since its foundation. It has not been easy and neither was it uncomplicated to contact the most important national and international personalities in the field of research, education and dental practice.

They have rallied around the idea of putting together a new journal for colleagues from Romania, the Republic of Moldova and the other former communist countries in Central and Eastern Europe only after being informed that the well-known Professor Jean-François Roulet of the Department of Restorative Dental Science, The College of Dentistry, University of Florida, Gainesville, FL, USA, editor of three quoted journals, voluntarily accepted to coordinate the work of the Editorial Board of the Stomatology Edu Journal as Editor-in-Chief. Guided by this symbol of professionalism, fairness and editorial stringency, colleagues both from Romania and from abroad joined our team, including the renowned Professor for Cranio Maxillofacial and Oral Surgery, Rolf Ewers, Chairman em. at the Medical University of Vienna, Vienna, Austria.

Then there followed other colleagues who wanted to contribute to the development of this journal as Senior Editors, namely Professor Bruce R. Donoff of the Department of Oral and Maxillofacial Surgery, Dean at the Harvard University of Harvard University, Boston, MA, USA, Professor of Biomedical Optics Adrian Podoleanu, Head of the Applied Optics Group, University of Kent, Canterbury, UK and Professor Emeritus David Wray, Department of Oral Medicine at the University of Glasgow, UK. To provide the Journal with scientific weight in all areas of stomatology, a series of professors, well-known for their extensive professional experience, were invited to join the team as Emeritus Editors-in-Chief.Let me mention Professor Birte Melsen from Aarhus University, Aarhus, Denmark, Professor Prathip Phantumvanit from Thammasat University, Bangkok, Thailand, Professor Rudolf Slavicek of the Medical University of Vienna, Austria and the late Professor Emeritus Julian B. Woelfel of The Ohio State University, Columbus, USA.

Other distinguished colleagues enthusiasically joined ourteam, while efficiently contributing significant important articles to the Journal. They are our Co-Editors-in-Chief, namely Professor Nicoleta llie of the Department of Operative Dentistry and Periodontology of Ludwig-Maximilians-Universität Munich, Germany, Professor Alexandre Mersel, Director of FDl Europe, Geneva-Cointrin, Switzerland, Professor Constantinus Politis, Head of Oral and Maxillofacial Surgery at University of Leuven, Belgium,Professor Hom-Lay Wang of the Department of Periodontics and Oral Medicine at the University of Michigan, Ann Arbor, Ml, USA, Clinical Professor Mauro Marincola of the State University of Cartagena, Colombia, Professor George E. Romanos of the Department of Periodontology at Stony Brook University, NY, USA, Professor Mahesh Verma, Principal Director, Maulana Azad 
Institute of Dental Sciences New Delhi, India and recently Associate Professor Hiroshi Ogawa of the Department of Oral Health Science at Niigata University, Japan.

While attending the 2013 FDI Congress in 1stanbul, 1 met Professor Anton Sculean, Chairman of the Department of Periodontology at University of Berne, Switzerland and presented him with an advanced copy of our Journal. He looked at it as any thorough researcher would do it, and with the swiftness of a surgeon, he coldly replied that "an international journal appears only in English, and Abstracts are not justified in a national language!" After seeing all the journals published by the various publishing houses present at the FDI Congress, 1 left myself convinced. 1 suffered for Eminescu, our national poet, and the other major representatives of our culture! Back home, I found myself in front of a final obstacle, the English Language Editor team. Previously, for everything related to the publication of abstracts or articles abroad, 1 used to ask two old friends of mine, both of them English teachers, who were not familiar with the dentistry terminology, as one worked in aviation and the other in the field of virusology. Such an ambitious project could only be achieved with high linguistic expertise. 1 tried to see who was the Head of the English Language Department at the Faculty of Foreign Languages, University of Bucharest. I found Professor Dr. Alexandra Cornilescu's phone number, who was also the Dean of the Faculty back then. 1 called, and a meeting was scheduled at her office. She thumbed through the advanced copy of the Journal with the researcher's minuteness and a linguist's attention. After a few moments, in perfect silence, instead of shouting "Eureka! Eureka!" like Archimedes, she gave me the name of Associate Professor Roxana-Cristina Petcu. She told me that the lady was a very close co-worker, and that 1 could rest assured that everyting was going to work out to perfection, as she had excellent translation expertise. 1 contacted Associate Professor Petcu and presented her with the copy of the journal, stating that it had been published after having been corrected seven times. 1 also told her that after the first correction, when 1 had the impression that the document was good for printing, 1 experienced what a boxer goes through when he is knocked-out during the first round. With a linguist's exigency and exactness, she asked me for the first issue to assess it. After receiving the proof, I found that if Professor]-F Roulet has the ability to evaluate a manuscript from the point of view of scientific accuracy, the art of making a translation is another profession mastered only by professionals who practice it daily and continually improve it. Professor]-F Roulet reached the same conclusion when his Editorial [1], published in the 2017 Stoma Edu ] number 2 and corrected by Professor Roxana-Cristina Petcu, was published in Dental Materials [2], Factor Impact journal (IF): 4.070. Indeed, 1 can say that without the constant contribution of the exceptional linguist who is Professor Roxana-Cristina Petcu, the 143,00o readers of the Stomatology Edu Journal, would not have had the joy to read a high-level publication from the very beginning.

The first and second 2014 issues of the Stomatology Edu Journal were published by SC Media Systems Communication SRL. Besides the task of finding articles for publication, the publishing house asked me to provide sponsors before sending each issue to print. Despite all the advertising contracts concluded for 2015 and 2016, the publishing house claimed that their accounts had been frozen, therefore, in 2015, it did not send to print any issues, neither did it send the first 2016 issue. The lack of honesty and professionalism of this company forced me to put an end to our collaboration. In order to honor Florin, my son's and my own promises to a foreign company, and especially to safeguard our country's image, we released 250 CDs with the first 2016 issue of the Stoma Edu ] carrying the advertisment of the company that had made full payment for all advertising materials. 1 myself paid for those $250 \mathrm{CDs}$. Florin attended the congress organized by that company, he himself delivered the 
CDs, which were well received in lieu of the journals, and were included in the congress folders. 1 regret to have to say that 1 understood that you could not trust a private company and 1 had to look for a state-owned publishing house.

After a brief analysis 1 understood that only the Publishing House of the Romanian Academy was the one to take over the publication of the journal. 1 approached the director of the Publishing House, Academician D. R. Popescu, and following our discussion 1 understood that the Romanian Academy Publishing House only publishes journals included in the portfolio of publications approved by the Presidium of the Romanian Academy. 1 submitted an application to the Presidium of the Romanian Academy in which 1 described the editorial board and the purpose of the journal. In response, 1 was advised to seek the agreement of the Academy of Medical Sciences, as there was no member of the Romanian Academy on our board, there were only members of the medical branch. Given this situation, 1 asked to be received by the person in charge of the Academy publications, its vicepresident, Academician Alexandru Surdu. Very kindly, he advised me to include at least one full member of the Academy in the Editorial Board and not to request any funds for publication. So 1 contacted Professor Constantin lonescu-Tirgoviște, member of the Romanian Academy and president of the Romanian Medical Association. With the courtesy of the master, he accepted to help us, especially as between diabetes and the periodontal disease there are a series of connections. It so happened that, at that time, a famous American professor of Romanian origin, Adrian Bejan, honorary member of the Romanian Academy, was in Bucharest to hold a conference in the Polytechnic University. 1 described the stomatologists' problem to him and 1 invited him to become a board member as Deputy Editor in Chief, as between his constructal theory, the stomatognathic system and the whole body there are a series of laws that draw us closer. As generousily as any great master or any elite athlete he accepted this position.

Then, with a substantially strengthened board, 1 appealed to the members of the journal board, holders of academic titles in their own countries, to recommend and support the Journal with the Romanian Academy. This is how the Office of the Presidium of the Romanian Academy received letters of recommendation and support from the German National Academy of Sciences Leopoldina (founded 1652) by Professor Gottfried Schmalz, The Croatian Academy of Sciences and Arts (founded 1866) by Professor Vjekoslav Jerolimov, l'Academie Nationale de Chirugie Dentaire (founded 1956) by Professor François Duret and Doctor Hubert - Pierre Ouvrard, DDS, PhD, former President of the l'Academie Nationale de Chirugie Dentaire (ANCD) and President of the l'Association d'Enseignement d'Odontologie et de Stomatologie. Following this cumulated approach, 1 was finally granted the approval of the Office of the Presidium of the Romanian Academy that the Stomatology Edu Journal (Stoma Edu J) be included in the portfolio of Romanian Academy journals, mentioning that the publication will be selffinanced.

After relating this journey, 1 still remember that, while we were on board an imposing yacht in the Tasman Sea, a colleague wearing a seaman's uniform ironically replied that he did not see the purpose of a new dental journal because there are too many already. It might be so for somebody who has free access to quoted journals.

The colleague wearing a seaman's uniform did not understand the urgent need to publish the over 85,000 dentists in the Central and Eastern European countries had [3]. The figure I quoted covers the 2013 census and out of this figure there are 15,500 dentists in Romania and 1,600 in the Republic of Moldova.

1 personally know that there are no specialized journals in our country, and, like my colleagues, 1 had to resort to 
quoted journals in other fields. Only in this way have 1 been able to publish articles and earn the required credits for promotion. It was an undertaking 1 had to clearly embark upon, the more so as the oldest specialized journal in our country, the Romanian Journal of Stomatology, published sincerg23, is rated only B +. Publishing an article in a journal with an high IF is difficult. Successfully publishing an article with a group of Italian colleagues after almost four years determined and motivated me to continue my work!

Due to the readiness manifested by Professor Michael Glick, DMD, Editor-in-Chief of the Journal of the American Dental Association, JADA [4], Mr. Michael Springer, Publisher, JADA, Mr. Nawin Gupta, Director of Business Operations, ADA and Mrs Stefanie K. Jewell-Thomas, Elsevier, due to their exceptional generosity and willingness to share scientific information, since our first 2017 issue we have been receiving an article with CE Program FAOs to be accessed by our readers.

Also in 2017, in order to increase the visibility of the online and print publication of the Stomatology Edu Journal, we asked Crossref to assign a single alphanumeric string, the Digital Object Identifier (DOI) [5]. The DOI identification is to be retrospectively assigned to all articles published starting with the first issue.

For the Stomatology Edu Journal to be included in the list of quoted publications starting with its 2017 number 3 , all references to articles published online must include DOI and active links from PubMed, Google Scholar and Scopus. It was, in fact, a broad retrospective integrating process.

The Stomatology Edu Journal, the publication that has been published online and in print since 2014, is recognized by a number of databases, such as the National Library of Medicine (NLM) [6], Crossref, SHERPA / RoMEO, Google Scholar, InfoBase Index (1BI Factor 2015: 2,76) and Academia edu. Currently, as a result of the efforts of our editors, the Stomatology Edu Journal is being evaluated by the Scientific Index Services (SIS) and the Directory of Open Access Journals (DOA]), and this year is subject to admission to Medline, PubMed Central (PMC) and Emerging Survey Citation Index (ESCl).

In order to meet these new requirements, as of the first 2018 number, the first page of each article has a new design, while the online version includes an abstract, a pdf, $x \mathrm{xl}$, and $\mathrm{htm}$ l format as well as references. It is a very time-consuming activity, carried out by the newest member of the operative editorial team, the very competent and energetic Professor Gabriel Octavian Lazăr, as Deputy Editor-in-Chief.

Professor Emeritus, Stephen F. Rosenstiel, from the Ohio State University, Columbus, USA, Reviewer-in-Chief, together with his team, played a decisive role in the publication by the Stoma Edu J of its over 95 articles. In 2017 a series of prestigious Academic Editors joined this team. Until now, after monitoring the visibility of articles published by the Stoma Edu ], we found the following articles on the Academia.edu site: Salivary and Serum Enzymes as Diagnostic Biomarkers in Patients with Periodontal Disease by Miricescu D, et al., 2014, 191 views; Silk fibroin and potential uses in regenerative dentistry - a systematic review by Virlan MJR, et al., 2014, 159 views; Treatment effects of R-appliance in vertically growing patients-case series by Showkatbakhsh R, et al., 2014, 112 views; Fundamentals of occlusion and masticatory function by Meyer GB, et al., 91 views; The use of rotation instruments in endodontic treatment of older dental patients by Retsas A., et al., 2015, 86 views; An implant supported maxillary fixed prosthesis with a substructure-suprastructure-design and clinical case by Kempler], 2014, 84 views; Remineralisation of affected dentine by different bioactive materials in the stepwise excavation technique by Andrian S, et al., 74 views [7].

The readers of the Stomatology Edu Journal are highly appreciative of the support provided by the prestigious 
publishing houses which have been generous enough to send us their latest publications to be reviewed in our Journal. Here they are: Quintessence International, Quintessence Publishing Company, Inc., Jaypee Brothers Medical Publishers (P) Ltd, Quintessence Editora - Sao Paulo , Brazil, Nova Science Publishers, Inc., Georg Thieme Verlag KG, Lippincott Williams \&Wilkins, Quintessenz Verlag, Thieme Publishers, dentaConcept, and ExistlT Publisher. 1 am honored to mention the initial contribution of Prof. Christian KNELLESEN and Prof. Jean-Louis GIOVANNOLI from Quintessence International, and then the effective and constant support of Mrs. Karin Wintonowycz and Dr. h.c. H.-W. Haase from Quintessenz Verlag-GmbH to regularly send us the requested books for review.

It is a significant example of support allowing our readers to have the continuous opportunity to be informed about the latest publications in all areas of dentistry starting with the first issue of our journal.

The time has come now for us to thank all our sponsors who have made possible the publication of the Stomatology Edu Journal. Here they are: Hofigal, Gral Medical, Dr. Fischer-Dental Laboratory, SisoMM, Bicon Europe Ltd, Angelus Dental, Dentsply Sirona, and lvoclar Vivadent. They have all helped improve the quality of life of the patients of our more than 143,000 readers.

It is a stock-taking moment, so 1 warmly invite all our Editorial Board members to look at their activity as compared to that of their colleagues so as to find ways to improve it in the interest of our more than 143,00o readers.

In order to respond to the invitation extended by the Romanian Academy to stimulate the international dissemination of scientific information via the electronic archive - "Academica Romanian Index", 1 would like to ask every editor who considers himself an active member of the Board to send us by April 15 a 250-word CV on their contribution in the field, surname, name, scientific titles, current administrative titles, the logo of the institution and a recent $3.5 \times 4.5 \mathrm{~cm}$ color photograph.

On behalf of the entire editorial board, 1 would like to take this opportunity and wish you an Easter filled with peace, happiness and joy, and a year that is bright with blessings.

Sincerely yours,

$M-V$ Constantinescu

Editor-in-Chief

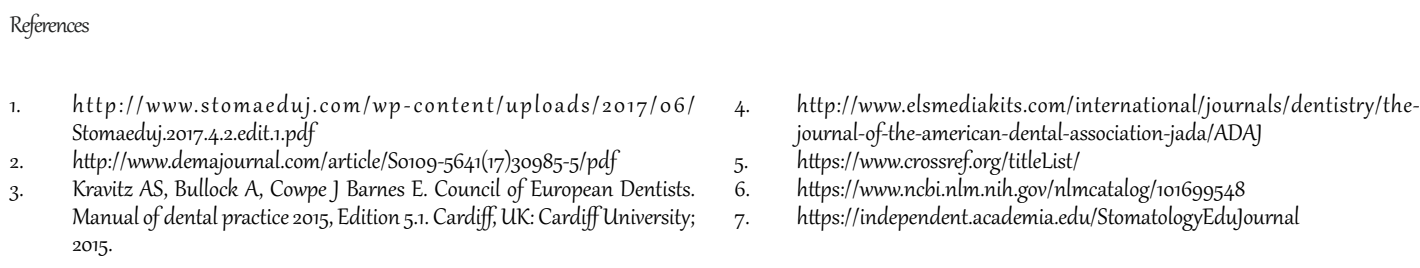

http://www.elsmediakits.com/international/journals/dentistry/thejournal-of-the-american-dental-association-jada/ADA] https://www.crossref.org/titleList/

https://www.ncbi.nlm.nih.gov/nlmcatalog/101699548 https://independent.academia.edu/StomatologyEdujournal 